\title{
Localized Distribution of Iris yellow spot virus Within Leeks and Its Reliable Large-Scale Detection
}

Tracey N. Smith, Plant Pathology Section, Department of Agriculture, Locked Bag No. 4, Bentley Delivery Centre, Perth, WA 6983, Australia, and Western Australian State Agricultural Biotechnology Centre, Murdoch University, Perth, WA 6150, Australia; Stephen J. Wylie, Centre for Legumes in Mediterranean Agriculture, University of Western Australia, Nedlands, Perth, WA 6009, Australia, and Western Australian State Agricultural Biotechnology Centre; Brenda A. Coutts, Plant Pathology Section, Department of Agriculture; and Roger A. C. Jones, Plant Pathology Section, Department of Agriculture, Centre for Legumes in Mediterranean Agriculture, University of Western Australia, and Western Australian State Agricultural Biotechnology Centre

\begin{abstract}
Smith, T. N., Wylie, S. J., Coutts, B. A., and Jones, R. A. C. 2006. Localized distribution of Iris yellow spot virus within leeks and its reliable large-scale detection. Plant Dis. 90:729-733.

In a survey to determine the incidence of Iris yellow spot virus (IYSV) in crops of several host species, samples of one leaf tip/plant were collected at random. When tested by enzyme-linked immunosorbent assay (ELISA) using IYSV-specific antibodies and a blocking step that improved test reliability, the virus was detected only in leek and onion. It was found in 11 of 21 leek and 2 of 26 onion plantings with apparent incidences of 1 to 7 and $1 \%$, respectively. However, the figures for leek crops greatly underestimate IYSV incidence due to localization of infection within plants. Thus, in tests on multiple subsections from individual plants, IYSV was detected in one or more leaves but never in all leaves. Within infected leaves, it was localized in patches of infection found mainly in the middle and top subsections of the unfurled leaves, but infrequently in their bases. It never was found in the furled leaves that make up the stems, or in the basal plates or roots. Therefore, to obtain reliable estimates of IYSV incidences in largescale surveys of leek crops, the randomly collected samples tested by ELISA should consist of combined tissue subsections from the tops and middles of several leaves from each plant sampled.
\end{abstract}

Additional keyword: Tospovirus

A tospovirus infecting onion (Allium сера) was reported in the United States in 1993 (10). It later was characterized from iris (Iris hollandica) and leek (A. porrum) in the Netherlands and named Iris yellow spot virus (IYSV; genus: Tospovirus, family: Bunyaviridae) (2). It subsequently has been identified infecting onion naturally in several major onion-producing states of the United States $(6,7,15,21)$. It was reported in Brazil and India in onion $(16,18,19)$; Slovenia in leek (14); Australia in onion and leek (3); Japan in lisianthus (Eustoma grandiflorum), amazon lily (Eucharis grandiflora), and St. Martin's lily ( $A l$ stroemeria ligtu) $(5,17,24)$; Israel in hippeastrum (Hippeastrum hybridum), onion, and lisianthus (Eustoma russellianum) $(8,11)$; and Reunion Island in leek, onion, garlic (A. sativum), and shallot (A. ascalonicum) (20). Once it becomes established

Corresponding author: R. A. C. Jones

E-mail: rjones@agric.wa.au

Accepted for publication 30 December 2005

DOI: 10.1094/PD-90-0729

(C) 2006 The American Phytopathological Society in an area, IYSV spreads rapidly in onion crops, e.g., in Colorado its incidence increased from $6 \%$ of fields tested in 2001 to $73 \%$ two years later (7). Reports of the economic losses caused by IYSV in onion range from high in Israel and Brazil $(11,18)$ to minimal in the Netherlands $(2)$. There are no reports of losses in other infected hosts.

Both enzyme-linked immunosorbent assay (ELISA; 2,3,7,11,12,19) and reversetranscription polymerase chain reaction (RT-PCR) assay $(2,6,11,18,20,24)$ are used to detect IYSV in samples from infected plants. Although the titer of IYSV in onion plants was highest in internal leaves and in segments of leaves closest to the bulb and least in the oldest leaves, it was detected by ELISA in all sections tested from different leaf parts. However, none was found in onion bulbs, roots, or seedlings grown from seed harvested from infected plants (12). Two other species of Tospovirus (Tomato spotted wilt virus [TSWV] and Impatiens necrotic spot virus [INSV]) behave similarly in having uneven titers in the leaves of infected plants of bulbous plant species (4).

In 2003, testing leaf samples using IYSV-specific antibodies in ELISA indi- cated that infection was widespread in crops of bulb onion, spring onion (A. fistulosum), and leek within market gardens in the Perth Metropolitan area in southwest Australia (3); later studies using RT-PCR and nucleotide sequencing (22) confirmed IYSV presence in leek and onion (GenBank accession nos. AY538778 and AY556424). However, nonspecific binding to ELISA plates caused by substances in extracts from leek, onion, and other hosts sometimes gave false-positive reactions.

This article reports that adding a blocking step removed false-positive results in ELISA providing a reliable detection procedure for IYSV in leaf samples, and that infection is localized within unfurled leek leaves and absent from the rest of an infected plant. The implications of these findings for the conduct of large-scale, ELISA-based surveys for IYSV involving samples collected at random from leek crops are discussed.

\section{MATERIALS AND METHODS}

Plants, virus isolates, inoculations, and antisera. All plants were grown in insect-proof, air-conditioned glasshouses and maintained at 15 to $20^{\circ} \mathrm{C}$. They were grown from seed, bulbs, or, for iris, obtained from a nursery. Those grown were onion cv. White Globe, leek cv. Sleek Leek, Nicotiana benthamiana, Chenopodium quinoa, C. amaranticolor, tulip (Tulipa sp. hybrid cv. Ad Rem), iris (cv. unknown), and Gomphrena globosa. IYSV isolate Vic-1 (GenBank accession no. AY345227), used as a positive control in ELISA, was obtained from D. Persley, Queensland Department of Primary Industries, Australia and cultured in N. benthamiana. Western Australian IYSV isolates WA-1 and WA-2 (GenBank accession nos. AY556424 and AY538778, respectively) were obtained from asymptomatic onion and leek plants, respectively, growing in market gardens in the Perth Metropolitan area of Western Australia. Tomato (Lycopersicon esculentum) cv. Grosse Lisse was the culture host for TSWV isolate $\mathrm{DA}_{\mathrm{WA}}-1$ (13). For virus inoculations, infected leaf tissue was ground in $0.05 \mathrm{M}$ potassium phosphate buffer ( $\mathrm{pH}$ 7.2) con- 
taining $0.05 \mathrm{M}$ sodium sulfite in a mortar and pestle and the sap mixed with the diatomaceous earth 'celite' before being rubbed onto leaves. Mock inoculations using tissue from healthy plants were done in the same way to establish healthy control plants. The three IYSV-specific polyclonal antisera used were from Loewe Biochemica, Saurerlach, Germany; DSMZ, Braunschweig, Germany; and Agdia Inc., Elkhart, IN. The polyclonal antiserum to other species of Tospovirus used were for TSWV, INSV, Groundnut ringspot virus (GRSV), and Tomato chlorotic spot virus (TCSV), all from Loewe Biochemica. The combined polyclonal antiserum specific to Tospovirus serogroups I, II, and III was also from Loewe Biochemica.

ELISA. Plant tissue samples were extracted $(1 \mathrm{~g} / 20 \mathrm{ml})$ in phosphate-buffered saline $(10 \mathrm{mM}$ potassium phosphate, 150 $\mathrm{mM}$ sodium chloride), $\mathrm{pH} 7.4$, containing Tween 20 at $5 \mathrm{ml} /$ liter and polyvinyl pyrrolidone at $20 \mathrm{~g} /$ liter (PBST) using a leaf press (Pollahne, Hannover, Germany). The double-antibody sandwich ELISA procedure used was as described previously (1). A series of experiments compared the reliability of ELISA tests done with and without a blocking step consisting of adding $5 \%(\mathrm{wt} / \mathrm{vol})$ skim milk powder to the conjugate buffer (23). The same five healthy onion plants and two healthy leek plants were used in each experiment. Controls included leaf samples from healthy $N$. benthamiana, $N$. benthamiana with IYSV isolate Vic-1, tomato with TSWV isolate $\mathrm{DA}_{\mathrm{WA}}-1$, and PBST only. Each series of

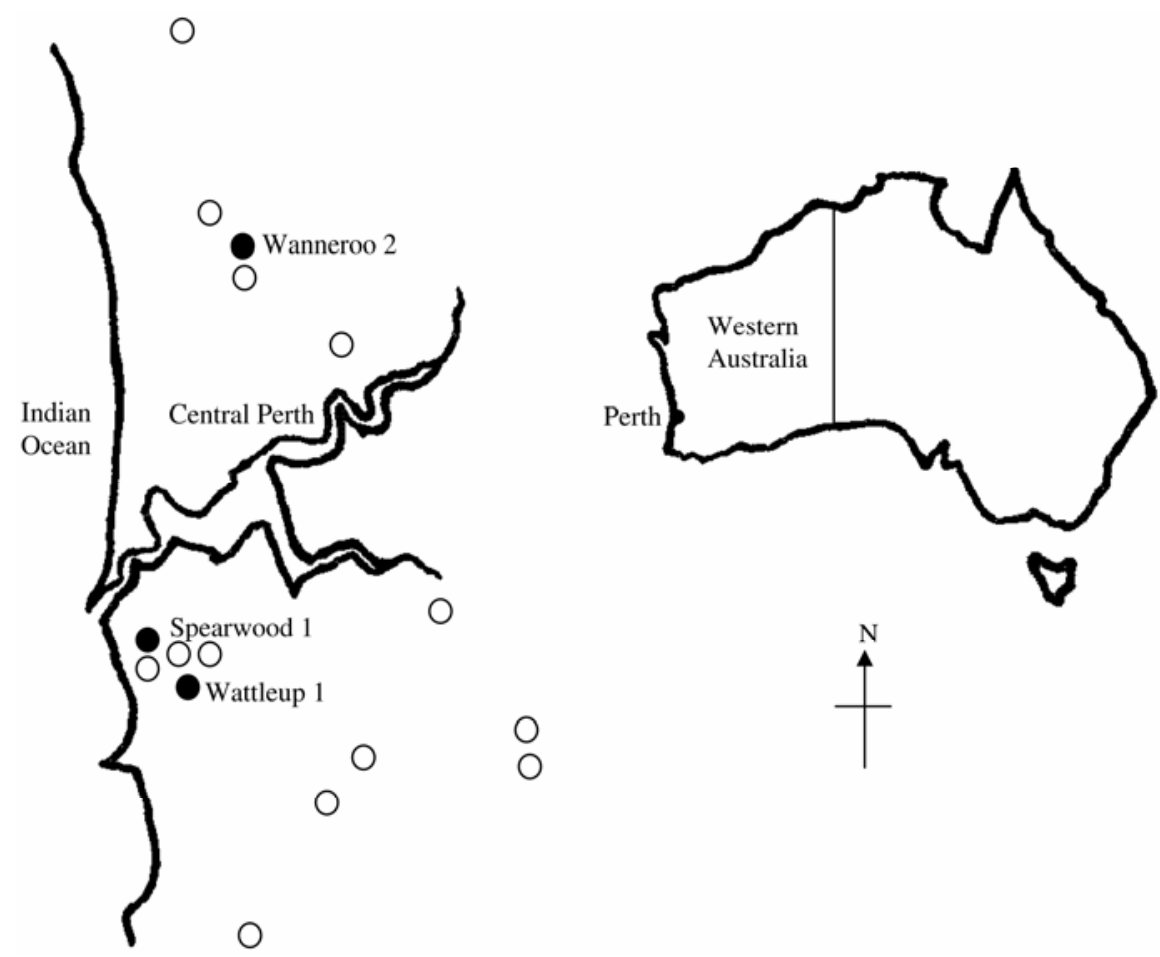

Fig. 1. Locations of market gardens and nurseries surveyed in the Perth Metropolitan area; Iris yellow spot virus (IYSV) detected $(\bullet)$ and not detected $(O)$. IYSV was detected in leek at Wanneroo 2 and Wattleup 1, and in onion at Spearwood 1. experiments using different antibodies always involved six identical experiments. Mean optical density (absorbance at 405 $\left.\mathrm{nm}\left[A_{405}\right]\right)$ values were calculated from the values obtained in each series of six identical experiments.

Survey. This survey was conducted during summer 2003-04 in the Perth Metropolitan area of Western Australia at 16 market gardens and nurseries (Fig. 1). Samples of leek were taken from eight crops at two market gardens, five seed production plantings at three market gardens, and eight seedling plantings from four market gardens and one nursery (Fig. 1). Bulb onion samples were from 19 bulb onion crops at seven market gardens, two seed production plantings at two market gardens, five seedling plantings from one market garden and two nurseries, and volunteer plants from one market garden. Spring onion samples were from 13 crops at four market gardens and two nurseries. Samples from one crop each of chive $(A$. schoenoprasum), garlic chive (A. tuberosum), shallot, and iris also were collected. Leaf tip samples were from the second youngest leaf of plants selected randomly without regard to presence or absence of symptoms, and, wherever possible, there were 100 or more such samples from each crop. Fewer samples were collected only where plantings were too small to provide 100 samples (e.g., in seedling nurseries where 10 to 80 samples were taken per planting). For each host species, the total numbers of samples collected were 2,810 of leek (cvs. Sleek Leek and unknown),
5,335 of bulb onion (from brown, red, and white bulb cultivars), 2,710 of spring onion (cvs. Ishikura, Nebuka, and unknown), 10 each of shallot and garlic chive, 20 of chive, and 100 of iris (cv. unknown). Samples were tested in groups of 10 and percent infection was determined from grouped sample test results as described previously (9). Controls included PBST alone and extracts from healthy leek, onion, and iris and IYSV-infected $N$. benthamiana. ELISA was with DSMZ antiserum, and a blocking step always was included.

Distribution experiment. Thirty-two plants were selected at random from a leek crop (at the Wattleup 1 market garden) that had a previous history of IYSV infection based on tests on one leaf tip per plant. All plants in this crop were asymptomatic. Each plant was divided into sections (Fig. 2 ). The roots were divided into four subsections that included inner and outer tissue, tips, and base. Basal plates were divided into two subsections consisting of inner and outer tissue. The stem, consisting of furled leaves and, where present, the young seed scape, was cut into $4-\mathrm{cm}$ lengths and these were further divided into inner and outer subsections. Each unfurled leaf was cut into base, middle, and top subsections. In the four plants that were flowering, tissue samples from emerged seed scapes and flowers within the same plant were combined. Controls were as above. Each subsection sample was tested separately by ELISA using DSMZ IYSVspecific antiserum with a blocking step included.

\section{RESULTS}

IYSV detection by ELISA. In a series of experiments with three different IYSV antisera and a generic Tospovirus antiserum without a blocking step, the mean optical density $\left(A_{405}\right)$ values in ELISA for sample extracts from healthy leek and onion plants were sometimes $>10$ times those obtained when the blocking step was included (Table 1). This effect was greater with the DSMZ antiserum where falsepositive ( 0.11 to 0.50$)$ and borderline $(0.06$ to 0.10$) A_{405}$ values sometimes were recorded when the $A_{405}$ value for the same samples with a blocking step was only 0.01. With the IYSV antisera from Loewe and Agdia and the Loewe generic Tospovirus antiserum were tested, false-positive and borderline $A_{405}$ values also were obtained, but to a lesser extent than with the DSMZ antiserum, especially with the Loewe polyclonal antiserum. Such potentially positive $A_{405}$ values were never obtained with the healthy $N$. benthamiana or tomato leaf sample extracts. True positive $A_{405}$ values with the IYSV-infected $N$. benthamiana sample extracts were 0.39 to 1.75 and these values were little altered by using the blocking agent. Generic Tospovirus antiserum gave positive values with 
TSWV-containing but not IYSVcontaining extracts. When antisera to TSWV, INSV, GRSV, and TCSV were substituted in otherwise identical sets of experiments, these also sometimes produced similar high $A_{405}$ values with extracts from healthy leek and onion plants in the absence but not in the presence of the blocking agent (data not shown). Similar results were obtained when identical experiments were done with the three IYSV antisera and extracts from healthy plants of tulip cv. Ad Rem (data not shown). Thus, when the blocking step was used in ELISA, any potential false-positive $A_{405}$ values obtained with extracts from different plant species always were eliminated.

Inoculations to indicator hosts. Following inoculation with infective sap,
IYSV isolate WA-2 from leek infected four indicator host species in inoculated leaves only. G. globosa and C. amaranticolor developed local lesions consisting of necrotic spots surrounded by chlorotic or red halos, respectively. $N$. benthamiana developed local necrotic spot lesions and $C$. quinoa was infected symptomlessly in inoculated leaves. ELISA tests on samples from inoculated and young uninoculated leaves 2 to 4 weeks and 6 weeks after inoculation, respectively, confirmed the presence of the virus in the former but found none in the latter.

Survey. When single leaf-tip samples from randomly selected leek plants within 21 plantings on five market gardens and a seedling nursery were tested for IYSV, the virus was detected in five production crops, three seed crops, and three seedling

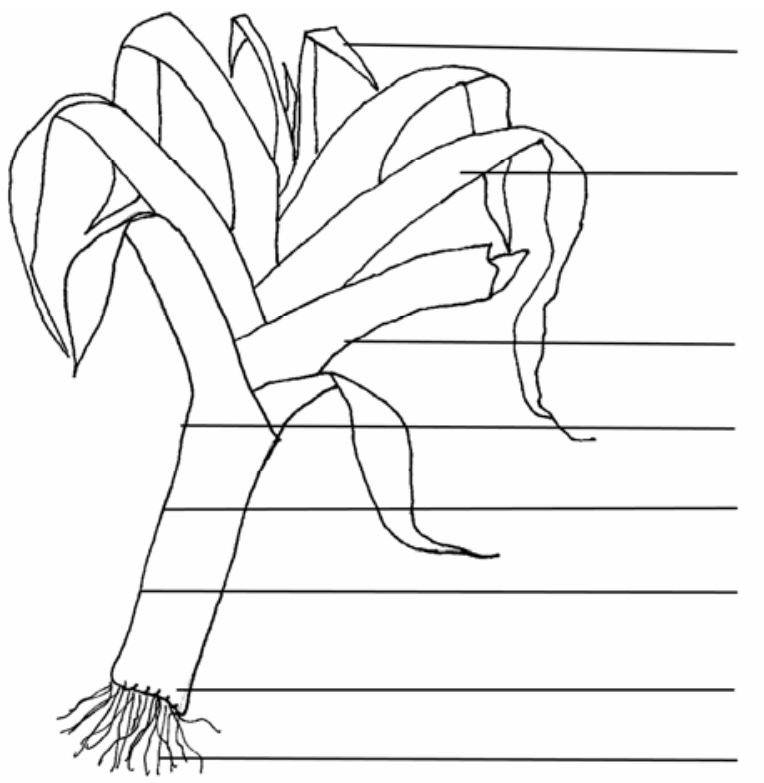

Leaf top subsection

Leaf middle subsection

Leaf base subsection

Stem section

Stem section

Stem section

Basal plate section

Root section

Fig. 2. Representation of a leek plant showing the positions of tissue sections and subsections tested by enzyme-linked immunosorbent assay. Stem sections were taken at $4-\mathrm{cm}$ intervals. plantings at two market gardens at 1 to $7 \%$ infected crop incidences (Table 2). When samples from 26 onion plantings at nine market gardens were tested similarly, IYSV was detected by ELISA at $1 \%$ incidence in two production crops at one market garden. Positive ELISA $A_{405}$ values were 16 to 260 times greater than background values. The virus was not detected in any of the samples tested of spring onion, shallot, garlic chive, chive, or iris.

Virus distribution within leek plants. When subsection samples from 32 plants chosen at random from an infected leek crop were tested, 26 of 32 plants $(81 \%)$ were found to contain IYSV in at least one leaf tissue subsection (Table 3). The virus was detected only in the unfurled leaves, where its distribution was patchy. It never was found in all leaves on any infected plant or in the stem (consists of furled leaves and developing seed scape), the emerged seed scape, the basal plate, or the roots. Within individual unfurled leaves, IYSV was detected more often in the top and middle subsections of the younger leaves than in their basal subsections or in old (outer) leaves. In 15 of 26 infected plants, adjacent leaves were infected in pairs five times, triples two times, quadruples once, and batches of 5 to 8 nine times. There were 18 isolated single infections on nonadjacent leaves in the remaining 11 plants. Within the same leaf, the virus was detected in single leaf subsections 59 times, in two adjacent subsections 29 times, and in three adjacent subsections 3 times. In the 96 adjacent subsections that were recorded as negatives (i.e., $A_{405}$ values 0.01 to 0.10$), 70$ had values of $0.01,10$ had values of 0.02 to 0.04 , and 16 had values of 0.05 to 0.10 . There was no clear gradient of virus titer, as determined by magnitude of $A_{405}$ values, in relation to subsection position within the leaf, or to leaf position (Table 4).

Table 1. Effect of a blocking step on the magnitude of enzyme-linked immunosorbent assay optical density values (absorbance at $\left.405 \mathrm{~nm}\left[A_{405}\right]\right)$ with different Tospovirus antibodies and healthy onion and leek tissue extracts

\begin{tabular}{|c|c|c|c|c|c|c|c|c|c|c|c|c|c|c|c|c|}
\hline \multirow[b]{4}{*}{ Plant } & \multicolumn{16}{|c|}{ Experiment series, with and without (W/o) blockinga } \\
\hline & \multicolumn{4}{|c|}{ DSMZ IYSV } & \multicolumn{4}{|c|}{ Loewe IYSV } & \multicolumn{4}{|c|}{ Agdia IYSV } & \multicolumn{4}{|c|}{ Generic Tospovirus } \\
\hline & \multicolumn{2}{|c|}{ Series 1} & \multicolumn{2}{|c|}{ Series 2} & \multicolumn{2}{|c|}{ Series 3} & \multicolumn{2}{|c|}{ Series 4} & \multicolumn{2}{|c|}{ Series 5} & \multicolumn{2}{|c|}{ Series 6} & \multicolumn{2}{|c|}{ Series 7} & \multicolumn{2}{|c|}{ Series 8} \\
\hline & W/o & With & W/o & With & W/o & With & W/o & With & W/o & With & W/o & With & W/o & With & W/o & With \\
\hline Onion 1 & 0.23 & 0.01 & 0.23 & 0.0 & 0.02 & 0.0 & 0.01 & 0.01 & $(0.10)$ & 0.01 & 0.12 & 0.01 & 0.01 & 0.01 & 0.01 & 0.01 \\
\hline Onion 2 & 0.12 & 0.01 & $(0.10)$ & 0.01 & 0.03 & 0.01 & 0.04 & 0.01 & 0.05 & 0.01 & $(0.06)$ & 0.01 & $(0.07)$ & 0.01 & $(0.06)$ & 0.01 \\
\hline Onion 3 & 0.32 & 0.01 & 0.30 & 0.01 & 0.01 & 0.01 & 0.01 & 0.01 & $(0.06)$ & 0.01 & $(0.07)$ & 0.01 & 0.02 & 0.01 & 0.03 & 0.01 \\
\hline Onion 4 & 0.53 & 0.01 & 0.54 & 0.01 & 0.01 & 0.01 & 0.01 & 0.01 & $(0.09)$ & 0.01 & $(0.09)$ & 0.01 & 0.15 & 0.01 & 0.15 & 0.01 \\
\hline Onion 5 & $(0.08)$ & 0.01 & $(0.08)$ & 0.01 & 0.02 & 0.01 & 0.01 & 0.01 & 0.02 & 0.01 & 0.17 & 0.01 & 0.03 & 0.01 & 0.04 & 0.01 \\
\hline Leek 1 & 0.05 & 0.01 & 0.04 & 0.01 & 0.05 & 0.01 & 0.05 & 0.01 & 0.01 & 0.01 & 0.03 & 0.01 & $(0.09)$ & 0.01 & $(0.10)$ & 0.01 \\
\hline Leek 2 & 0.22 & 0.01 & 0.23 & 0.01 & $(0.07)$ & 0.01 & $(0.06)$ & 0.01 & 0.02 & 0.01 & 0.04 & 0.01 & 0.01 & 0.01 & 0.01 & 0.01 \\
\hline N. ben. $^{\mathrm{b}}$ with IYSV & 0.82 & 0.80 & NT & NT & NT & NT & 0.61 & 0.39 & 1.76 & 1.75 & NT & NT & 0.01 & 0.01 & 0.01 & 0.01 \\
\hline Tomato with TSWV ${ }^{c}$ & 0.01 & 0.01 & 0.01 & 0.01 & 0.01 & 0.01 & 0.01 & 0.01 & 0.01 & 0.01 & 0.01 & 0.01 & NT & NT & 0.55 & 0.45 \\
\hline$N$. ben., healthy & 0.01 & 0.01 & 0.02 & 0.01 & 0.01 & 0.01 & 0.01 & 0.01 & 0.01 & 0.01 & 0.01 & 0.01 & 0.01 & 0.01 & 0.01 & 0.01 \\
\hline Buffer only & 0.01 & 0.01 & 0.01 & 0.02 & 0.01 & 0.01 & 0.01 & 0.01 & 0.01 & 0.01 & 0.02 & 0.01 & 0.01 & 0.01 & 0.01 & 0.01 \\
\hline
\end{tabular}

${ }^{a}$ IYSV = Iris yellow spot virus. Each $A_{405}$ value represents the mean from six identical experiments. Values for onion and leek $>10$ times those of the blocking step value are marked in bold; figures 6 to 10 times this value are shown in parentheses. The diverse antibodies used are indicated in the column headings; NT $=$ not tested.

${ }^{\mathrm{b}}$ N. ben. $=$ Nicotiana benthamiana .

c TSWV = Tomato spotted wilt virus . 


\section{DISCUSSION}

This study revealed that IYSV infection occurs in localized patches within the unfurled leaves of leek plants and does not move systemically to other parts of the plant. It also demonstrated that a blocking step is beneficial in ELISA to achieve reliable testing for IYSV infection in samples of leek, onion, and other hosts. Our study differs from most previous ones on IYSV in these crops because it did not rely on use of symptomatic plant tissue, often from the seed scape, for testing. Instead, it was based entirely on tissue from asymptomatic plant parts.

Reliable detection of IYSV in leaf samples was hampered because extracts of healthy onion, leek, and some other hosts, e.g., tulip, sometimes caused false-positive $A_{405}$ values in ELISA. The magnitude of this effect was greatest with the DSMZ antiserum but also was evident to a greater or lesser degree with all the other antibodies used. A simple modification involving addition of a blocking agent (5\% skim milk powder) to the conjugate buffer (23) proved very effective in eliminating the false positives. Gent et al. (7) used an alternative procedure to detect IYSV in symptomatic onion tissue by ELISA. It involved grinding the leaf tissue in liquid nitrogen before adding an extraction buffer that included egg albumin. However, such a labor-intensive procedure would not be suitable for use in large-scale, highthroughput sample testing. Others did not report whether they used specific modifications to their ELISA procedures to help detect IYSV in onion tissue reliably $(3,12,18)$.

The patchy distribution of IYSV found in leaves of naturally infected leek plants, low incidence of infection in the young basal leaf tissue closest to the meristem, and absence of it from other plant parts indicates that the virus does not move systemically in this species. If it did move systemically, it would be likely to occur particularly in the basal portions of all infected leaves and spread to most young leaves on infected plants. This was not the

Table 2. Incidence of Iris yellow spot virus (IYSV) in samples from plantings of susceptible crops in the Perth Metropolitan area

\begin{tabular}{|c|c|c|c|c|c|c|}
\hline \multirow[b]{2}{*}{ Crop } & \multicolumn{5}{|c|}{ Number of } & \multirow[b]{2}{*}{ Infection $(\%)^{\mathrm{c}}$} \\
\hline & $\begin{array}{l}\text { Market gardens } \\
\text { (nurseries) sampled }\end{array}$ & $\begin{array}{l}\text { Plantings } \\
\text { sampled }\end{array}$ & $\begin{array}{l}\text { Leaf samples } \\
\text { tested }\end{array}$ & $\begin{array}{l}\text { Market gardens } \\
\text { with IYSV }^{\mathbf{b}}\end{array}$ & $\begin{array}{l}\text { Plantings with } \\
\text { IYSV }\end{array}$ & \\
\hline Leek crop & 2 & 8 & 1,340 & $1(\mathrm{Wn} 2)$ & 5 & $1-5$ \\
\hline Leek seed crop & 3 & 5 & 780 & 1 (Wt1) & 3 & $1-7$ \\
\hline Leek seedlings & $4(1)$ & 8 & 690 & $2(\mathrm{Wn} 2, \mathrm{Wt} 1)$ & 3 & $1-3$ \\
\hline Onion bulb crop & 7 & 19 & 4,900 & $1(\mathrm{Sp} 1)$ & 2 & 1 \\
\hline Onion seed crop & 2 & 2 & 140 & 0 & 0 & 0 \\
\hline Onion seedlings & $1(2)$ & 5 & 275 & 0 & 0 & 0 \\
\hline Onion volunteers & 1 & 1 & 20 & 0 & 0 & 0 \\
\hline Spring onion & $4(2)$ & 13 & 2,710 & 0 & 0 & 0 \\
\hline Other Allium spp. & (1) & 3 & 40 & 0 & 0 & 0 \\
\hline Iris & 1 & 1 & 100 & 0 & 0 & 0 \\
\hline
\end{tabular}

${ }^{a}$ Based on one tip leaf sample/plant tested by enzyme-linked immunosorbent assay with a blocking step. All positive optical density values (absorbance at $\left.405 \mathrm{~nm}\left[A_{405}\right]\right)$ were $>16$ times those of the healthy control samples

${ }^{\mathrm{b}}$ Market garden code: $\mathrm{Wn} 2=$ Wanneroo 2, Wt1 $=$ Wattelup 1 , and Sp1 $=$ Spearwood 1.

${ }^{c}$ Incidence of IYSV infection.

Table 3. Location of Iris yellow spot virus (IYSV) within the unfurled leaves of naturally infected leek plants as determined by enzyme-linked immunosorbent assay

\begin{tabular}{|c|c|c|c|c|c|c|c|}
\hline \multirow[b]{2}{*}{ Leaf age $^{c}$} & \multirow[b]{2}{*}{ No. of plants tested } & \multicolumn{3}{|c|}{ Location of subsection $^{a}$} & \multicolumn{3}{|c|}{ Frequency of virus detection ${ }^{b}$} \\
\hline & & Base & Middle & Top & Singles & Doubles & Triples \\
\hline 1 & 26 & 0 & $3(3)$ & $6(2)$ & 3 & 3 & 0 \\
\hline 2 & 26 & 1 & $5(1)$ & $12(2)$ & 11 & 2 & 1 \\
\hline 3 & 26 & 2 & 7 (3) & $7(4)$ & 12 & 2 & 0 \\
\hline 4 & 26 & $2(1)$ & $10(2)$ & $13(5)$ & 13 & 6 & 0 \\
\hline 5 & 26 & $1(1)$ & 11 & $11(1)$ & 5 & 9 & 0 \\
\hline 6 & 25 & 0 & $6(1)$ & $7(2)$ & 5 & 4 & 0 \\
\hline 7 & 24 & $1(1)$ & $4(2)$ & $4(1)$ & 4 & 1 & 1 \\
\hline 8 & 21 & $1(1)$ & $5(1)$ & $2(1)$ & 4 & 2 & 0 \\
\hline 9 & 13 & 1 & $2(1)$ & 2 & 2 & 0 & 1 \\
\hline 10 & 8 & 0 & 0 & 0 & 0 & 0 & 0 \\
\hline 11 & 4 & 0 & 0 & 0 & 0 & 0 & 0 \\
\hline TOTAL & $\ldots$ & $8(4)$ & $53(14)$ & $64(18)$ & 59 & 29 & 3 \\
\hline
\end{tabular}

${ }^{\text {a }}$ Healthy control optical density values (absorbance at $405 \mathrm{~nm}\left[A_{405}\right]$ ) were always 0.01 or less and sections were considered positive when $>10$ times this value (i.e., $>0.10)$. Borderline $A_{405}$ values $(0.06$ to 0.10$)$ are shown in parentheses.

${ }^{\mathrm{b}}$ Singles = number of detections in one leaf subsection, doubles = detections in two adjacent leaf subsections, and triples = detections in three adjacent leaf subsections (borderline values excluded).

${ }^{\mathrm{c}}$ Leaf age from youngest (1) to oldest (11).

Table 4. Titers of Iris yellow spot virus (IYSV) as determined by enzyme-linked immunosorbent assay (ELISA) optical density values (absorbance at 405 $\left.\mathrm{nm}\left[A_{405}\right]\right)$ for samples from the infected subsections of the unfurled leaves of 26 naturally infected leek plants ${ }^{\mathrm{a}}$

\begin{tabular}{lccccccccc}
\hline $\begin{array}{l}\text { Leaf } \\
\text { subsection }\end{array}$ & Leaf 1 & Leaf 2 & Leaf 3 & Leaf 4 & Leaf 5 & Leaf 6 & Leaf 7 & Leaf 8 & $\begin{array}{c}\text { Healthy leaf } \\
\text { sample }\end{array}$ \\
\hline Top & $0.33(6)$ & $0.49(12)$ & $0.86(7)$ & $0.63(13)$ & $0.61(11)$ & $0.71(7)$ & $0.48(4)$ & $0.22(2)$ & 0.01 \\
Middle & $0.43(4)$ & $0.48(5)$ & $0.58(7)$ & $0.67(10)$ & $0.55(11)$ & $0.46(6)$ & $0.44(4)$ & $0.48(5)$ & 0.01 \\
Base & $\ldots$ & $0.14(1)$ & $0.55(2)$ & $0.31(2)$ & $0.23(1)$ & $\ldots$ & $1.21(1)$ & $0.24(1)$ & 0.01 \\
\hline
\end{tabular}

${ }^{a}$ Mean ELISA $A_{405}$ values for infected leaf subsections from partially infected leek plants. Values $>10$ times those of the healthy control samples were considered positive. Values in parentheses are numbers of leaf subsections in which IYSV was detected. 
case because infection was found mostly in older leaf tissue (middle and top portions) and only rarely in localized parts of all young leaves. In contrast, IYSV is found in onion plants throughout the unfurled leaf (12). A plausible explanation for leek is that IYSV remains localized within each section of unfurled leaf to which it was introduced by a viruliferous individual of its Thrips tabaci vector (12), only spreading slowly from cell to cell rather than systemically via the phloem. Where isolated patches of infection occur, each would reflect introduction by a single viruliferous thrips. Multiple inoculations by different viruliferous thrips would explain the presence of infection patches in distant unfurled leaves on the same plant. There was no virus concentration gradient within individual unfurled leaves. In leek, IYSV infection occurred more often in two or more adjacent unfurled leaves than it did in nonadjacent leaves, possibly reflecting the behavior of single viruliferous $T$. tabaci moving about locally between nearby leaves.

The typical symptoms of IYSV reported elsewhere in infected leek and onion $(6,7,14,19,20)$ were not seen in our studies, where infection was asymptomatic, and there was no evidence of any detrimental effect on them. Possibly, the symptomless, localized infection we found in leek represents a form of resistance or tolerance to the virus. To investigate this further, it would be worthwhile to examine the reactions of different cultivars or wider leek germplasm to infection with IYSV. Although it infected four of the commonly used IYSV indicator hosts, including $N$. benthamiana, a local Australian isolate did not move systemically in any of them. In contrast, isolates from Brazil (18) and Israel (12) infected $N$. benthamiana systemically. The patchy distribution of IYSV infection within leek plants has important implications for the epidemiology of the virus in this host. For large-scale infection to be found in a leek crop, a potent source of the virus is required nearby and multiple inoculations by viruliferous thrips need to occur frequently throughout the crop. Where leek growers plant and harvest leek in successive side-by-side plantings all year round, there always are old, infected leek plants likely to act as foci for infection of young ones. A break from growing leek and other IYSV host crops altogether, along with efficient roguing of volunteers and other hygiene measures such as re- moval of cull piles, should help eliminate the virus source and, thereby, diminish spread of the virus. Our findings have important implications for the conduct of large-scale surveys to determine the incidence of IYSV in crops like leek, where infection by IYSV is mostly asymptomatic and the distribution of the virus is patchy within infected plants. To obtain an accurate incidence value, the middles and tops of the youngest five to six unfurled leaves should be collected from each randomly selected plant. Then, samples consisting of tissue subsections from both portions of each of the different leaf samples from each plant should be combined together for testing by ELISA, preferably using a labor-efficient sap extractor machine to prepare bulked sample extracts. Also, we recommend that a blocking step be included to eliminate possible false positive $A_{405}$ values.

\section{ACKNOWLEDGMENTS}

We thank the Department of Agriculture for Western Australia for financial support and E. Gajda for help with plant propagation.

\section{LITERATURE CITED}

1. Clark, M. F., and Adams, A. N. 1977. Characteristics of the microplate method of enzyme linked immunosorbent assay for the detection of plant viruses. J. Gen. Virol. 34:475-483.

2. Cortês, I., Livieratos, I. C., Derks, A., Peters, D., and Kormelink, R. 1998. Molecular and serological characterization of iris yellow spot virus, a new and distinct tospovirus species. Phytopathology 88:1276-1282.

3. Coutts, B. A., McMichael, L. A., Tesoriero, L., Rodoni, B. C., Wilson, C. R., Wilson, A. J., Persley, D. M., and Jones, R. A. C. 2003. Iris yellow spot virus found infecting onions in three Australian states. Australas. Plant Pathol. 32:555-557.

4. Derks, A. F. L. M., and Lemmers, M. E. C. 1996. Detection of tospoviruses in bulbous crops and transmissibility by vegetative propagation. Acta Hortic. 432:132-137.

5. Doi, M., Zen, S., Okuda, M., Nakamura, H., Kato, K., and Hanada, K. 2003. Leaf necrosis disease of lisianthus (Eustoma grandiflorum) caused by Iris yellow spot virus. Jpn. J. Phytopathol. 69:181-188.

6. du Toit, L. J., Pappu, H. R., Druffel, K. L., and Pelter, G. Q. 2004. Iris yellow spot virus in onion bulb and seed crops in Washington. Plant Dis. 88:222.

7. Gent, D. H., Schwartz, H. F., and Khosla, R. 2004. Distribution and incidence of Iris yellow spot virus in Colorado and its relation to onion plant population and yield. Plant Dis. 88:446452.

8. Gera, A., Cohen, J., Salomon, R., and Raccah, B. 1998. Iris yellow spot tospovirus detected in onion (Allium cepa) in Israel. Plant Dis. 82:127.

9. Gibbs, A. J., and Gower, J. C. 1960. The use of a multiple transfer method in plant virus transmission studies-some statistical points arising in the analysis of results. Ann. Appl. Biol. 48:75-83.

10. Hall, J. M., Mohan, K., Knott, E. A., and Moyer, J. W. 1993. Tospoviruses associated with scape blight of onion (Allium cepa) seed crops in Idaho. Plant Dis. 77:952.

11. Kritzman, A., Beckelman, H., Alexandrov. S., Cohen, J., and Lampel, M., 2000. Lisianthus leaf necrosis: A new disease of lisianthus caused by Iris yellow spot virus. Plant Dis. 84:1185-1189.

12. Kritzman, A., Lampel, M., Raccah, B., and Gera, A. 2001. Distribution and transmission of Iris yellow spot virus. Plant Dis. 85:838842 .

13. Latham, L. J., and Jones R. A. C. 1997. Occurrence of tomato spotted wilt tospovirus in native flora, weeds and horticultural crops. Aust. J. Agric. Res. 48:359-369.

14. Mavri, I., Ravnikar, M., Zeidan, M., Raccah, B., and Gerra, A. 2003. Further characterization of a Slovenian isolate of Iris yellow spot tospovirus. (Abstr.) J. Plant Dis. Prot. 110:73.

15. Mullis, S. W., Langston, D. B., Jr., Gitaitis, R D., Sherwood, J. L., Csinos, A. C., Riley, D. G., Sparks, A. N., Torrance, R. L., and Cook, M. J. 2004. First report of Vidalia onion ( $A l$ lium cepa) naturally infected with Tomato spotted wilt virus and Iris yellow spot virus (family Bunyaviridae, genus Tospovirus) in Georgia. Plant Dis. 88:1285.

16. Nagata, T., Almeida, A. C. L., Resende, R. de O., and de Avila, A. C. 1999. The identification of the vector species of iris yellow spot tospovirus occurring on onion in Brazil. Plant Dis. 83:399.

17. Okuda, M., and Hanada, K. 2001. RT-PCR for detecting five distinct Tospovirus species using degenerate primers and dsRNA template. J. Virol. Methods 96:149-156.

18. Pozzer, L., Bezzera, I. C., Kormelink, R., Prins, M., Peters, D., Resende, R. de O., and de Avila, A. C. 1999. Characterization of a Tospovirus isolate of iris yellow spot virus associated with a disease in onion fields in Brazil. Plant Dis. 83:345-350.

19. Ravil, K. S., Kitkaru, A. S., and Winter S. 2005. Iris yellow spot virus in onions: a new Tospovirus record from India. New Dis. Rep. 11:Feb. 2005-July 2005.

20. Robène-Soustrade, I., Hostachy, B., RouxCuvelier, M., Minatchy, J., Hédont, M., Pallas, R., Couteau, A., Cassam N., and Wuster, G., 2005. First report of Iris yellow spot virus in onion bulb and seed production fields in Reunion Island. New Dis. Rep. 11:Feb. 2005-July 2005.

21. Schwartz, H. F., Brown, M. W., Jr. Blunt, T., and Gent, D. H. 2002. Iris yellow spot virus on onion in Colorado. Plant Dis. 86:560.

22. Smith, T. N., Jones, R. A. C., and Wylie, S. J. Genetic diversity of the nucleocapsid gene of Iris yellow spot virus. Australas. Plant Pathol. In press.

23. Towbin, H., and Gordon, J. 1984. Immunoblotting and dot immunobinding-current status and outlook. J. Immunol. Methods 72:313-340.

24. Uga, H., and Tsuda, S. 2005. A one-step reverse transcription-polymerase chain reaction system for the simultaneous detection and identification of multiple tospovirus infections. Phytopathology 95:166-171. 